\title{
LACK OF ASSOCIATION BETWEEN CONVALESCENT PLASMA ADMINISTRATION AND LENGTH OF HOSPITAL STAY: A HOSPITAL-DAY STRATIFIED MULTI-CENTER RETROSPECTIVE COHORT STUDY
}

\author{
Authors: \\ Joy Alamgir, ARIScience [corresponding author] \\ M. Ruhul Abid MD, PhD, Brown University Alpert Medical School [corresponding author] \\ Brian Garibaldi MD, Johns Hopkins Hospital \\ Naved Munir MD, CaroMont Health \\ Soko Setoguchi, MD, DrPH, Rutgers Robert Wood Johnson Medical School \\ Stephanie S. Hong BS, Johns Hopkins University School of Medicine \\ Xinci Chen MSc, ARIScience \\ Paul T. Kocis, PharmD, MPH, Penn State Health, M.S. Hershey Medical Center, Hershey, PA \\ Masanao Yajima PhD, Boston University, Department of Mathematics and Statistics \\ G. Caleb Alexander MD, MS, Johns Hopkins Bloomberg School of Public Health \\ Hemalkumar B. Mehta PhD, Johns Hopkins University \\ Vithal Madhira MS, Palila Software \\ Rosa Ergas, MPH, ARIScience \\ Thomas R. O'Brien MD, MPH, National Cancer Institute, National Institutes of Health \\ Sam Bozzette MD, PhD, National Center for Advancing Translational Science, National Institutes of \\ Health
}

\section{Correspondence}

Joy Alamgir

Principal Investigator

ARIScience

Email: joy@ariscience.com

148 Commonwealth Rd STE 5138

Wayland MA 01778

\author{
Ruhul Abid MD PhD \\ Associate Professor \\ Brown University Warren Alpert Medical School \\ Email: ruhul_abid@brown.edu \\ Cardiothoracic Surgery, Rhode Island Hospital \\ 1 Hoppin St, Providence RI 02903
}

Short Title: No Association between Convalescent Plasma Treatment for COVID-19 and Hospitalization Duration

Keywords: Convalescent plasma, SARS-CoV-2, COVID-19, Hospitalized Patients 
medRxiv preprint doi: https://doi.org/10.1101/2021.05.04.21256627; this version posted May 8, 2021. The copyright holder for this preprint (which was not certified by peer review) is the author/funder, who has granted medRxiv a license to display the preprint in perpetuity. It is made available under a CC-BY-NC 4.0 International license .

\section{ABSTRACT}

Background: Effects of timing of Convalescent plasma (CP) administration on hospitalized COVID-19 patients are not established.

Methods: We used the National COVID Cohort Collaborative data to perform a retrospective cohort study of hospitalized COVID-19 patients in the United States between 07-01-2020 and 12-19-2020. We stratified patients based on day of CP administration (Day 0, 1, 2, 3 and 4) from COVID-19 diagnosis. We used 35 predictors to frame matched cohorts accounting for clinical and sociodemographic characteristics. We used competing risk survival models to examine the association between CP administration and length of hospital stay with in-hospital death as a competing risk performing Gray's test on the cumulative incidence function and Cox's regression on cause specific hazard ratios.

Results: In a cohort of 4,003 hospitalized COVID-19 patients, 197 (4.9\%) received CP within the first 5 days following COVID-19 diagnosis. After adjusting for potential confounding variables, there were no statistically significant associations between day of CP administration and length of hospital stay. Day $0 \mathrm{CP}$ administration signalled lower mortality but was not statistically significant (HR 0.45 [0.19-1.03]).

Conclusions: We found no association between the timing of $\mathrm{CP}$ administration and length of stay among hospitalized COVID-19 patients. 
medRxiv preprint doi: https://doi.org/10.1101/2021.05.04.21256627; this version posted May 8, 2021. The copyright holder for this preprint (which was not certified by peer review) is the author/funder, who has granted medRxiv a license to display the preprint in perpetuity. It is made available under a CC-BY-NC 4.0 International license .

\section{INTRODUCTION}

As of April 5, 2021, 554,064 individuals have died and more than 30.5M have been infected with SARS-CoV-2, the virus that causes COVID-19, in the United States. ${ }^{1}$ Given the morbidity and mortality that the pandemic has posed, an extraordinary effort has been undertaken to identify effective treatments for COVID-19 in addition to vaccination efforts ${ }^{2}$. Among potential candidates under active investigation, there has been continued interest in the potential value of convalescent plasma (CP) given its availability from those who have recovered from COVID-19 infection. Federal Drug Administration (FDA) issued an emergency use authorization (EUA) for CP as a treatment for hospitalized COVID-19 patients on August 23, 2020. ${ }^{3}$

To better understand the potential effects of CP as a treatment for COVID-19, there have been studies in multiple countries (e.g., US, Argentina, Bahrain, China, India, Spain, The Netherlands) involving different patient populations. ${ }^{4-16}$ These studies, ranging from RCTs to observational studies, have evaluated the reduction in mortality and length of hospitalization, as well as other secondary endpoints. However the effectiveness of CP administration has been mixed in these studies. For example Gharbharan et al in their RCT reported no improvement in mortality and that by the time COVID-19 patients are hospitalized there are already neutralizing antibodies in the patients at a level comparable to donor CP. Simonovich et al and Agarwal et al in their respective RCTs also reported no difference in outcome with CP administration. In contrast Libster et al in their RCT reported improvement in disease progression. Observational studies, with or without matching, also reported conflicting results. For example Bodhiraj et al, and Liu et al, and Joyner et al observed improved outcomes from CP administration while Rogers et al and Sostin et al did not. There are several plausible reasons for differences in the conclusions drawn by these varied studies, including differences in study populations, timing of CP exposure, outcome ascertainment and statistical methods used. It is noteworthy that while some studies looked at early and late CP administration effects (Salazar et al) we were unable to find any studies that did a per-day stratification of the effect of CP administration to identify the specific effects of the timing of CP administration. This research aims to fill the knowledge gap related to timing of CP administration and COVID-19 outcomes.

In this analysis, we tested the hypothesis that CP administration reduces the duration of hospitalization in COVID-19 patients and that this reduction is dependent on the day of administration (Day 0, 1, 2, 3 and 4) of COVID-19 diagnosis. We used the National COVID Cohort Collaborative (N3C) $)^{17}$ data to test the hypothesis. 
medRxiv preprint doi: https://doi.org/10.1101/2021.05.04.21256627; this version posted May 8, 2021. The copyright holder for this preprint (which was not certified by peer review) is the author/funder, who has granted medRxiv a license to display the preprint in perpetuity. It is made available under a CC-BY-NC 4.0 International license.

\section{METHODS}

\section{N3C Data}

The N3C harmonizes Electronic Health Record data for COVID-19 tested persons dating from 01/01/2018. Data from 36 medical centers were securely transferred to the N3C data enclave and harmonized into a single common model. ${ }^{18-19}$ We included patients who were diagnosed and hospitalized with COVID-19 from July 1, 2020 to December 19, 2020. As of 12/19/2020, $\mathrm{N} 3 \mathrm{C}$ contained $2.5 \mathrm{M}$ total patients including 400K COVID-19 patients, 1.13B lab results, $472 \mathrm{M}$ drug exposures, and $185 \mathrm{M}$ procedures. We froze our analysis on that release to minimize confounding from COVID-19 vaccination, which began in the United States in mid-December 2020. ${ }^{20}$

\section{Study Institutions and Patients}

Figure 1 shows the population selection for this analysis and the distribution of day of CP administration as compared to COVID-19 diagnosis. Data-providers were excluded from the analysis if their data did not include specific codes or descriptions for CP data that allowed us to differentiate CP from other plasma products. ${ }^{21}$ Patients not diagnosed with COVID-19 were excluded. Patients for whom data on age or gender were missing were excluded. To focus on patients at higher risk of severe disease, we also excluded patients less than 30 years of age. Patients more than 85 years of age were excluded given the likelihood of other severe comorbidities that might have independently influenced their hospital stay and the possibility of death confounded by do-not-resuscitate, do-not intubate orders. We further restricted the analysis to patients who were hospitalized. To reduce confounding introduced by decreased COVID-19 mortality among hospitalized from March 2020 to July 2020, patients diagnosed with COVID-19 before July 1, 2020 were excluded. ${ }^{22}$ To eliminate the effect of COVID-19 vaccination in our analysis, we excluded patients diagnosed after December 19, 2020. We worked with N3C operational staff to identify a blacklist of patients from early in the COVID-19 pandemic. This blacklist methodology was required as our data access was de-identified with dates shifted $+/-180$ days. Thus effectively the time period of the cohort ranged from July 1, 2020 to December 19, 2020. Missing predictor data were handled using a constant value and separately a flag indicating that data were missing and as such were part of the propensity score calculation described below. ${ }^{23}$

Identification of Outcomes, Covariates and Treatment

We assessed live discharge from hospitalization, and thus hospitalization duration from treatment or in-hospital death as the two outcomes. Live discharge was determined through N3C harmonized_visit table which collates information from visit_occurrence table. ${ }^{18}$ In-hospital death was determined through the death table provided such death occurred during hospitalization. ${ }^{24}$ Covariates (i.e. predictors) were identified using OHDSI ${ }^{24,25}$ concept sets. Treatment (CP administration) was identified by case insensitive string matching *TRANSFUSION*CONVALESCENT* device_exposure or procedure_occurrence tables. ${ }^{19}$ String matching was used as opposed to code sets because CP transfusion information was sent as free text as opposed to coded set by the subset of $\mathrm{N} 3 \mathrm{C}$ data providers sending CP information. 
medRxiv preprint doi: https://doi.org/10.1101/2021.05.04.21256627; this version posted May 8, 2021. The copyright holder for this preprint (which was not certified by peer review) is the author/funder, who has granted medRxiv a license to display the preprint in perpetuity. It is made available under a CC-BY-NC 4.0 International license .

\section{Statistical Analysis}

We performed multi-predictor propensity score based cohort matching to account confounding in the compared cohorts. ${ }^{26,27}$ The 26 pre-COVID-19 diagnosis predictors used to construct a propensity score model for cohort matching were: gender, age, race, geographical region, Charlson Comorbidity Index $(\mathrm{CCl})^{28}$ categories $(0,1,2-3,4-5,6+)$, dexamethasone, specific $\mathrm{CCl}$ conditions (cancer, HIV, myocardial infarction, stroke, rheumatic disease, peripheral vascular disease, renal disease, congestive heart failure), prior medical disposition (smoker, diabetic, chronic respiratory disorder, hypertensive, hyper cholesterol), prior access to medical care (through prior monthly outpatient, inpatient and ER visits, medication, procedure, hospitalization rates), BMI and data provider. We additionally used 9 Day-of-CP-Administration predictors which included minimum systolic blood pressure, minimum Glomerular Filtration Rate (GFR), minimum $\mathrm{O} 2$ saturation, minimum bicarbonate, maximum respiratory rate, maximum heart rate, maximum temperature, maximum C-reactive protein (CRP) and maximum erythrocyte sedimentation rate (ESR) rate. We used a Bayesian logistic model ${ }^{29}$ to have numerically stable estimates. Patients who received CP were divided into subsets that received plasma only on Day 0, 1, 2, 3 and 4 and not prior to that specified day. For each subset a cohort was created using propensity scores via nearest neighbor matching with replacement (Figure 2). ${ }^{27}$ For each cohort we performed survival analysis ${ }^{30,31}$ using Cumulative Incidence Function (CIF) (3) $^{32}$ and followed up with Gray's CIF equality test. ${ }^{33}$ CIF estimates the incidence of the occurrence of an event (live discharge) while taking into account competing risk (death) while Gray's test appropriately ${ }^{34}$ determines the significance of treatment on the competing events we analyzed. ${ }^{30-16}$ For each cohort we also performed cause specific hazard ratios ${ }^{30}$ at $95 \%$ confidence interval followed up with Cox's test. ${ }^{31} \mathrm{~A}$ hazard ratio $>1.0$ indicates a beneficial effect on risk of live hospital discharge. A hazard ratio of $<1.0$ indicates a beneficial effect on risk of mortality. The outcome of interest for the survival analysis was live hospital discharge with death as a competing risk. We developed Java/Python/R routines to prepare and analyze N3C data. COVID-19 diagnosis was determined through non-immunoglobulin based COVID-19 tests.

Specific Day-of-CP-Administration predictors were used as they are general markers of patient state and have been shown to be important in prediction models for COVID-19 severity and in comparative effectiveness analyses for COVID-19 therapeutics. Minimum GFR was used as a marker for renal function, minimum $\mathrm{O} 2$ saturation and maximum respiratory rate were used as markers of respiratory disease. Bicarbonate was used as a marker for tissue perfusion. Maximum ESR, maximum CRP, maximum temperature, and maximum heart rate were used as markers for inflammation. ${ }^{35-38}$ Follow-up was censored at 84 days.

\section{RESULTS}

After excluding patients from providers that did not encode CP, that were age or gender, or were diagnosed with COVID-19 prior to July 1, 2020, there were 4,003 patients hospitalized with COVID-19, of whom $312(7.7 \%)$ had received CP within 14 days of COVID-19 diagnosis (Figure 1). 
medRxiv preprint doi: https://doi.org/10.1101/2021.05.04.21256627; this version posted May 8, 2021. The copyright holder for this preprint (which was not certified by peer review) is the author/funder, who has granted medRxiv a license to display the preprint in perpetuity. It is made available under a CC-BY-NC 4.0 International license .

In the above cohort, 197 (4.9\%) received CP within Day 0, 1, 2, 3 or 4 of COVID-19 diagnosis. Multi-predictor propensity score matching based on both pre-COVID-19 predictors and Day-of-CP-Administration predictors produced a matched comparison cohort for each treatment day. As a visual example, the predictor match for CP administered on day 0 is shown in Figure 2.

Table 1 shows the characteristics of the patients who received CP treatment and the matched cohorts for each treatment day. Overall, treated patients were predominately white $(63 \%)$ and male $(57 \%)$ with a mean age of 64 . Of particular note is that these patients tended to be overweight or obese (mean BMI: $32 \mathrm{~kg} / \mathrm{m}^{\wedge} 2$ ); $44 \%$ were without prior comorbidities based on $\mathrm{CCl}, 46 \%$ were hypertensive, $37 \%$ diabetic and $12 \%$ with chronic respiratory issues. The matched cohort tracks these numbers closely overall except for day 4 which shows specifically smoker, diabetic, Charlson comorbidity predictor asymmetricity.

For each of Day 0, 1, 2, 3 and 4, we failed to detect any statistically significant reduction in hospitalization duration through both Gray's CIF equality test and Cox's cause-specific hazard ratio tests (Table 2 and Figure 3). For the CP-administered on day 0 , the cause-specific death hazard ratio was 0.45 but this association was not significant ( $p$-value 0.06 ). For the $\mathrm{CP}$-administered on day 4 , there was a statistically significant increased death hazard ratio (Table 2 and Figure 3) but as the cohort size $(\mathrm{N}=28)$ was low for the day 4 analysis, and as smoker, diabetic, Charlson comorbidity matching were asymmetric, we are unable to come to a definitive conclusion for day 4.

\section{DISCUSSION}

In this study, treatment with CP on Day 0, 1, 2, 3 and 4 of COVID-19 diagnosis demonstrated no significant effect on duration of hospitalization among COVID-19 patients. In addition to duration of hospitalization as determined by live discharge from the hospital, in-hospital deaths were also assessed in this study which also showed no association with CP treatment.

Assessment of the effectiveness of CP administration has shown mixed results across RCT and observational studies as summarized in Table 3. When comparing the results of our study with those of prior studies, following key points were observed:

- Findings are consistent with 5 of the RCTs of Table 3 (Simonovich et al, Horby et al, Agarwal et al, Li et al, Gharbaran et al)

- Findings are inconsistent with 1 of the RCTs (Libster et al).

- Findings are consistent with two of the observational studies that performed patient matching (Rogers et al, Sostin et al)

- Findings are inconsistent with two of the observational studies that performed patient (Salazar et al, Liu et al).

- Findings are inconsistent with the only observational studies that did not perform patient matching (Budhiraja et al)

- The Joyner et al study is not comparable as it did not compare effect of CP administration with a control group that did not receive $\mathrm{CP}$ 
medRxiv preprint doi: https://doi.org/10.1101/2021.05.04.21256627; this version posted May 8, 2021. The copyright holder for this preprint (which was not certified by peer review) is the author/funder, who has granted medRxiv a license to display the preprint in perpetuity. It is made available under a CC-BY-NC 4.0 International license .

The studies with which our results are inconsistent can be further de-constructed. The Budhiraja et al study reported significant positive outcomes for patients admitted to ICU and administered CP. This ICU+CP treated cohort had 171 people over 60 years of age compared to 184 people over 60 years of age in the control cohort and a significant difference given effect of age on COVID-19 mortality. ${ }^{39}$ Additionally, the same study had $30 \%$ less people with $3+$ co-morbidities in the ICU+CP treated group compared to control group which is also a significant difference given the effect of multiple co-morbidities in COVID-19 mortality. ${ }^{40}$ In Salazar et al and Liu et al the number of patients with CP included in the statistical analysis was 143 and 39 , which is $27 \%$ and $80 \%$ lower than the number of patients with CP that was analyzed in our study. Finally, the Libster et al RCT was reasonably comparable between treated and untreated groups except for age where the number of people over 75 years old was $20 \%$ higher in the untreated group $(\mathrm{N}=48)$ as compared to the treated group $(\mathrm{N}=40)$ - a significant difference given effect of age on COVID-19 disease progression and mortality. ${ }^{39}$

Stratified analysis of effect of CP administration on specific days on or after COVID-19 diagnosis and the use of markers for inflammation, respiratory distress and renal function on specific CP administration days employed in this study provide an objective view into efficacy of CP treatment on duration of COVID-19 related hospitalization.

\section{Limitations}

Administration of CP was not consistently coded in the N3C data. To restrict our analysis to patients who had received CP rather than other plasma products, we excluded all data from providers without specific codes or descriptions for CP data. That restriction reduced our potential population by over $90 \%$. While we attempted to match patient severity using 9 day of CP predictors based on data available within N3C, there could be other predictors that better represent patient status for matching purposes. Furthermore, the study could be augmented, pending data availability, with information on the oxygen device that was used during the treatment period. Another limitation is that the N3C dataset did not track whether a patient was involved in a COVID-19 vaccination trial which may skew results. This, however, is unlikely as vaccinated individuals are unlikely to be hospitalized for COVID-19 given the timeframe this analysis considered is between 07/01/2020 and 12/19/2020. Finally, while the research team considered use of titer and blood type, the analyzed N3C dataset did not contain titer levels of $\mathrm{CP}$ that was administered and was sparse in blood type information.

\section{Future work}

Our data do not demonstrate any clear benefit for CP administration in hospitalized patients with COVID-19 within the first 4 days of hospitalization. There was a trend towards reduced mortality for CP administered on Day 0 but a potential for increased mortality if administered on day 4. More work needs to be done to understand the possibility that earlier treatment may have a beneficial effect on COVID-19 outcomes, particularly as decades ago research pointed to similar observations ${ }^{41}$, versus the possibility that later treatment may be harmful. 
medRxiv preprint doi: https://doi.org/10.1101/2021.05.04.21256627; this version posted May 8, 2021. The copyright holder for this preprint (which was not certified by peer review) is the author/funder, who has granted medRxiv a license to display the preprint in perpetuity. It is made available under a CC-BY-NC 4.0 International license.

\section{ACKNOWLEDGEMENTS}

The statistical analyses we performed were conducted with data or tools accessed through the NCATS N3C Data Enclave and supported by NCATS U24 TR002306. This research was possible because of the patients whose information is included within the data and the organizations and scientists who have contributed to the on-going development of this community resource. ${ }^{17}$ This work was supported by the Intramural Research Program of the National Institutes of Health, National Cancer Institute, Division of Cancer Epidemiology and Genetics. The content of this publication and the opinions expressed do not necessarily reflect the views or policies of the Department of Health and Human Services, the National Institutes of Health or the National Cancer Institute nor does mention of trade names, commercial products, or organizations imply endorsement by the U.S. Government. We also acknowledge support from the N3C Publication Committee in the preparation of this manuscript.

\section{COMPETING INTEREST/CONFLICTS OF INTEREST}

Joy Alamgir is founder of ARIScience. Dr. Alexander is past Chair and a current member of FDA's Peripheral and Central Nervous System Advisory Committee; is a co-founding Principal and equity holder in Monument Analytics, a health care consultancy whose clients include the life sciences industry as well as plaintiffs in opioid litigation; and is a past member of OptumRx's National P\&T Committee. Brian Garibaldi has received consulting fees from Janssen Research and Development, LLC and serves on the FDA Pulmonary-Asthma Drug Advisory Committee. This arrangement has been reviewed and approved by Johns Hopkins University in accordance with its conflict of interest policies

\section{AUTHOR CONTRIBUTIONS}

JA, SS, PK, XC wrote the first draft of the manuscript. JA, SS, MY, BG, RE, HM, CA, XC set up the statistical test design. RA, NM, BG, SB, PK, TO provided clinical input and patient severity predictor considerations and use thereof. $X C$ wrote $R$ code that was reviewed by JA, MY, SS. JA, SH, XC wrote data preparation code. TO, PK, CA, SB, VM, JA provided existing CP literature support. SB spurred the initial idea to look at CP within N3C. All authors reviewed and edited the manuscript. JA, XC, RE prepared tables and figures with input from other authors. Authorship was determined using ICMJE recommendations.

\section{AVAILABILITY OF DATA AND MATERIALS}

National Institute of Health's (NIH) National COVID Cohort Collaborative (N3C) has clear procedures for researchers to gain access to the data (1000+ researchers already have access to the data) and as such the patient statistical analysis of this manuscript is transparent and repeatable. https://ncats.nih.gov/n3c provides data access request process details.

Supplementary materials to this manuscript provided at https://www.ariscience.org/p3 sc2 paper 03.html include R analysis code.

\section{PATIENT CONSENT FOR PUBLICATION}

Not Applicable

\section{ETHICS APPROVAL AND CONSENT TO PARTICIPATE}

National Institute of Health's (NIH) National COVID Cohort Collaborative (N3C) Data Utilization Request Approval committee approved the data utilization request of this project (RP-C80011) 
medRxiv preprint doi: https://doi.org/10.1101/2021.05.04.21256627; this version posted May 8, 2021. The copyright holder for this preprint (which was not certified by peer review) is the author/funder, who has granted medRxiv a license to display the preprint in perpetuity. It is made available under a CC-BY-NC 4.0 International license.

FUNDING: This research was partially funded by ARIScience. The N3C data project which this research utilized was funded by National Institutes of Health NCATS U24 TR002306. 
medRxiv preprint doi: https://doi.org/10.1101/2021.05.04.21256627; this version posted May 8, 2021. The copyright holder for this preprint (which was not certified by peer review) is the author/funder, who has granted medRxiv a license to display the preprint in perpetuity. It is made available under a CC-BY-NC 4.0 International license .

\section{REFERENCES}

1. CDC COVID Data Tracker. Centers for Disease Control and Prevention website. Updated April 5, 2021. Accessed April 6, 2021. https://covid.cdc.gov/covid-data-tracker/

2. COVID-19 Vaccines. Food and Drug Administration. Updated March 12, 2021. Accessed March 13, 2021.

https://www.fda.gov/emergency-preparedness-and-response/coronavirus-disease-2019-covid-19/covid-19 -vaccines

3. FDA Issues Emergency Use Authorization for Convalescent Plasma as Potential Promising COVID-19 Treatment, Another Achievement in Administration's Fight Against Pandemic. Food and Drug Administration. Updated March 12, 2021. Accessed March 13, 2021.

https://www.fda.gov/news-events/press-announcements/fda-issues-emergency-use-authorization-convale scent-plasma-potential-promising-covid-19-treatment

4. Joyner M.J., Carter R.E, Senefeld J.W., et al., Convalescent Plasma Antibody Levels and the Risk of Death from Covid-19. New England Journal of Medicine, 2021. DOI: 10.1056/NEJMoa2031893

5. Simonovich VA, Burgos Pratx LD, Scibona P, et al. A Randomized Trial of Convalescent Plasma in Covid-19 Severe Pneumonia. N Engl J Med. 2021 Feb 18;384(7):619-629. doi:

10.1056/NEJMoa2031304. Epub 2020 Nov 24. PMID: 33232588; PMCID: PMC7722692.

6. Libster R, Pérez Marc G, Wappner D., et al., Early High-Titer Plasma Therapy to Prevent Severe Covid-19 in Older Adults. New England Journal of Medicine, 2021.

7. Horby PW, Estcourt L, Peto L, et al. Convalescent plasma in patients admitted to hospital with COVID-19 (RECOVERY): a randomised, controlled, open-label, platform trial. medRxiv. 2021:2021.2003.2009.21252736.

8. Agarwal A, Mukherjee A, Kumar $G$ et al. Convalescent plasma in the management of moderate COVID-19 in adults in India: open label phase II multicentre randomised controlled trial (PLACID Trial). BMJ. 2020;371:m3939. doi:10.1136/bmj.m3939

9. Li L, Zhang W, Hu Y, et al. Effect of convalescent plasma therapy on time to clinical improvement in patients with severe and life-threatening COVID-19: a randomized clinical trial. JAMA.

2020;324(5):460-470. doi:10.1001/jama.2020.10044

10. Janiaud P, Axfors C, Schmitt AM, et al. Association of Convalescent Plasma Treatment With Clinical Outcomes in Patients With COVID-19: A Systematic Review and Meta-analysis. JAMA.

2021;325(12):1185-1195.

11. Rogers R, Shehadeh F, Mylona EK, et al. Convalescent plasma for patients with severe COVID-19: a matched cohort study. Clin Infect Dis. 2020 Oct 10:ciaa1548. doi: 10.1093/cid/ciaa1548. Epub ahead of print. PMID: 33038227; PMCID: PMC7665324.

12. Sostin OV, Rajapakse P, Cruser B, Wakefield D, Cruser D, Petrini J. A matched cohort study of convalescent plasma therapy for COVID-19. J Clin Apher. 2021 Feb 22. doi: 10.1002/jca.21888. Epub ahead of print. PMID: 33616257.

13. Salazar E et al. Treatment of Coronavirus Disease 2019 Patients with Convalescent Plasma Reveals a Signal of Significantly Decreased Mortality. Am J Pathol. 2020 Nov;190(11):2290-2303. doi:

10.1016/j.ajpath.2020.08.001. Epub 2020 Aug 11. PMID: 32795424; PMCID: PMC7417901.

14. Liu et al. Convalescent plasma treatment of severe COVID-19: a propensity score-matched control study. Nat Med. 2020 Nov;26(11):1708-1713. doi: 10.1038/s41591-020-1088-9. Epub 2020 Sep 15.

PMID: 32934372.

15. Gharbharan A. Convalescent plasma for covid-19. A randomized clinical trial. medRxiv 2020:2020.07.01.20139857. [Preprint.] doi:10.1101/2020.07.01.20139857v1

16. Budhiraja S, Dewan A, Aggarwal R, Singh O, Juneja D, Pathak S, Singh YP, Gupta A, Rai R, Indrayan A, Jha V, Naithani R. Effectiveness of convalescent plasma in Indian patients with COVID-19. Blood Cells 
medRxiv preprint doi: https://doi.org/10.1101/2021.05.04.21256627; this version posted May 8, 2021. The copyright holder for this preprint (which was not certified by peer review) is the author/funder, who has granted medRxiv a license to display the preprint in perpetuity. It is made available under a CC-BY-NC 4.0 International license .

Mol Dis. 2021 May;88:102548. doi: 10.1016/j.bcmd.2021.102548. Epub 2021 Feb 18. PMID: 33621948; PMCID: PMC7891064.

17. Melissa A Haendel, Christopher G Chute, Tellen D Bennett, et al. The National COVID Cohort Collaborative (N3C): Rationale, design, infrastructure, and deployment, JAMIA Aug 2020. DOI: 10.1093/jamia/ocaa196

18. Tellen D. Bennett, Richard A. Moffitt, Janos G. Hajagos,, et al: The National COVID Cohort Collaborative: Clinical Characterization and Early Severity Prediction medRxiv 2021.01.12.21249511; doi:https://doi.org/10.1101/2021.01.12.21249511

19. OMOP Common Data Model. Updated Oct 10, 2018. Accessed Mar 24, 2021. https://github.com/OHDSI/CommonDataModel/blob/master/OMOP CDM v6 0.pdf

20. First COVID-19 Vaccine Given. British Broadcasting Corporation. Updated December 14, 2020. Accessed March 13, 2021. https://www.bbc.com/news/world-us-canada-55305720

21. Johnson S, Speedie S, Simon G, Kumar V, Westra B. Quantifying the Effect of Data Quality on the Validity of an eMeasure. Appl Clin Inform. 2017;8(4):1012-1021. DOI:10.4338/ACI-2017-03-RA-0042

22. Ledford $H$. Why do COVID death rates seem to be falling? Nature. 2020 Nov;587(7833):190-192. doi: 10.1038/d41586-020-03132-4. PMID: 33177662.

23. Rosenbaum P. Design of Observational Studies. Springer Series in Statistics. Pp 193-194. DOI: 10.1007/978-1-4419-1213-8

24. OMOP/N3C Templates and Codes. ARIScience. Updated December 18, 2020. Accessed December 19, 2020. https://www.ariscience.org/y1 omop n3c.html.

25. Atlas OHDSI concept sets. Updated Dec 18 2020. Accessed Mar 24, 2021. http://atlas-covid19.ohdsi.org/\#/home

26. Ho D, Imai K, King G, Stuart E. Matchlt: Nonparametric Preprocessing for Parametric Causal Inference. J. Stat. Softw. 2011;Vol. 42, No. 8, pp. 1-28. DOI: 10.18637/jss.v042.i08

27. Stuart E. Matching methods for causal inference: A review and a look forward. Stat Sci.

2010;25(1):1-21. DOI:10.1214/09-STS313

28. Charlson M, Szatrowski TP, Peterson J, Gold J. Validation of a combined comorbidity index. J Clin Epidemiol. 1994 Nov;47(11):1245-51. doi: 10.1016/0895-4356(94)90129-5. PMID: 7722560.

29. Goodrich B, Gabry J, Ali I, Brilleman S (2020). "rstanarm: Bayesian applied regression modeling via Stan." R package version 2.21.1. https://mc-stan.org/rstanarm

30. Austin PC, Lee DS, Fine JP. Introduction to the Analysis of Survival Data in the Presence of Competing Risks. Circulation. 2016 Feb 9;133(6):601-9. doi: 10.1161/CIRCULATIONAHA.115.017719. PMID: 26858290; PMCID: PMC4741409.

31. Noordzij M, Leffondré K, van Stralen KJ, Zoccali C, Dekker FW, Jager KJ. When do we need competing risks methods for survival analysis in nephrology? Nephrol Dial Transplant. 2013 Nov;28(11):2670-7. doi: 10.1093/ndt/gft355. Epub 2013 Aug 24. PMID: 23975843.

32. Scrucca, L., Santucci, A. \& Aversa, F. Competing risk analysis using R: an easy guide for clinicians. Bone Marrow Transplant 40, 381-387 (2007). https://doi.org/10.1038/sj.bmt.1705727 https://www.nature.com/articles/1705727.

33. Gray RJ: A class of K-sample tests for comparing the cumulative incidence of a competing risk. Ann Stat 16:1141-1154, 1988

34. Williamson PR, Kolamunnage-Dona R, Tudur Smith C. The influence of competing-risks setting on the choice of hypothesis test for treatment effect. Biostatistics. 2007 Oct;8(4):689-94. doi:

10.1093/biostatistics/kxl040. Epub 2006 Dec 6. PMID: 17151088.

35. Wongvibulsin S, Garibaldi BT, Antar AAR, Wen J, Wang MC, Gupta A, Bollinger R, Xu Y, Wang K, Betz JF, Muschelli J, Bandeen-Roche K, Zeger SL, Robinson ML. Development of Severe COVID-19 Adaptive Risk Predictor (SCARP), a Calculator to Predict Severe Disease or Death in Hospitalized Patients With COVID-19. Ann Intern Med. 2021 Mar 2:M20-6754. doi: 10.7326/M20-6754. Epub ahead of print. PMID: 33646849; PMCID: PMC7934337. 
medRxiv preprint doi: https://doi.org/10.1101/2021.05.04.21256627; this version posted May 8, 2021. The copyright holder for this preprint (which was not certified by peer review) is the author/funder, who has granted medRxiv a license to display the preprint in perpetuity. It is made available under a CC-BY-NC 4.0 International license .

36. Garibaldi BT, Fiksel J, Muschelli J, et al. Patient Trajectories Among Persons Hospitalized for COVID-19 : A Cohort Study [published correction appears in Ann Intern Med. 2021 Jan;174(1):144]. Ann Intern Med. 2021;174(1):33-41. doi:10.7326/M20-3905

37. Garibaldi BT, Wang K, Robinson ML, Zeger SL, Bandeen-Roche K, Wang MC, Alexander GC, Gupta A, Bollinger R, Xu Y. Comparison of Time to Clinical Improvement With vs Without Remdesivir Treatment in Hospitalized Patients With COVID-19. JAMA Netw Open. 2021 Mar 1;4(3):e213071. doi: 10.1001/jamanetworkopen.2021.3071. PMID: 33760094.

38. Ignatius EH, Wang K, Karaba A, Robinson M, Avery RK, Blair P, Chida N, Jain T, Petty BG, Siddiqui Z, Melia MT, Auwaerter PG, Xu Y, Garibaldi BT. Tocilizumab for the Treatment of COVID-19 Among Hospitalized Patients: A Matched Retrospective Cohort Analysis. Open Forum Infect Dis. 2020 Dec 28;8(1):ofaa598. doi: 10.1093/ofid/ofaa598. PMID: 33537364; PMCID: PMC7798657.

39. O'Driscoll M, Ribeiro Dos Santos G, Wang L, Cummings DAT, Azman AS, Paireau J, Fontanet A, Cauchemez S, Salje H. Age-specific mortality and immunity patterns of SARS-CoV-2. Nature. 2021 Feb;590(7844):140-145. doi: 10.1038/s41586-020-2918-0. Epub 2020 Nov 2. PMID: 33137809. 40. Harrison SL, Fazio-Eynullayeva E, Lane DA, Underhill P, Lip GYH. Comorbidities associated with mortality in 31,461 adults with COVID-19 in the United States: A federated electronic medical record analysis. PLoS Med. 2020;17(9):e1003321. Published 2020 Sep 10. doi:10.1371/journal.pmed.1003321 41. Cecil RL. Effects of Early Serum Treatment on Pneumococcus Type I Pneumonia. Trans Am Clin Climatol Assoc. 1936;52:52-63. 


\section{TABLES}

Table 1: Characteristics of patients treated with convalescent plasma (CP) on (Day 0, 1, 2, 3 and 4) after COVID-19 diagnosis and propensity matched controls.

\begin{tabular}{|c|c|c|c|c|c|c|c|c|c|c|c|c|}
\hline \multirow{2}{*}{\begin{tabular}{|l} 
Day of CP \\
Administration \\
Characteristic
\end{tabular}} & \multicolumn{2}{|l|}{ Day 0} & \multicolumn{2}{|l|}{ Day 1} & \multicolumn{2}{|l|}{ Day 2} & \multicolumn{2}{|l|}{ Day 3} & \multicolumn{2}{|l|}{ Day 4} & \multicolumn{2}{|c|}{ Overall Cohort } \\
\hline & $\begin{array}{l}\mathrm{CP} \\
\text { Treated }\end{array}$ & $\begin{array}{l}\text { Matched } \\
\text { Control }\end{array}$ & $\begin{array}{l}\text { CP } \\
\text { Treated }\end{array}$ & \begin{tabular}{|l|} 
Matched \\
Control
\end{tabular} & $\begin{array}{l}\mathrm{CP} \\
\text { Treated }\end{array}$ & $\begin{array}{l}\text { Matched } \\
\text { Control }\end{array}$ & $\begin{array}{l}\text { CP } \\
\text { Treated }\end{array}$ & $\begin{array}{l}\text { Matched } \\
\text { Control }\end{array}$ & $\begin{array}{l}\mathrm{CP} \\
\text { Treated }\end{array}$ & $\begin{array}{l}\text { Matched } \\
\text { Control }\end{array}$ & $\begin{array}{l}\mathrm{CP} \\
\text { Treated }\end{array}$ & \begin{tabular}{|l|} 
Matched \\
Control
\end{tabular} \\
\hline Total N & 48 & 48 & 69 & 69 & 25 & 25 & 27 & 27 & 28 & 28 & 197 & 197 \\
\hline Deaths N (\%) & $\begin{array}{r}9 \\
(18.75)\end{array}$ & $\begin{array}{r}15 \\
(31.25)\end{array}$ & $\begin{array}{r}12 \\
(17.39)\end{array}$ & $\begin{array}{r}10 \\
(14.49)\end{array}$ & $\begin{array}{r}4 \\
(16.0)\end{array}$ & $\begin{array}{r}2 \\
(8.0)\end{array}$ & $\begin{array}{r}4 \\
(14.81)\end{array}$ & $\begin{array}{r}6 \\
(22.22)\end{array}$ & $\begin{array}{r}8 \\
(28.57)\end{array}$ & $\begin{array}{r}2 \\
(7.14)\end{array}$ & $\begin{array}{r}37 \\
(18.78)\end{array}$ & $\begin{array}{r}35 \\
(17.77)\end{array}$ \\
\hline \begin{tabular}{|l} 
Average Age \\
(std)
\end{tabular} & $\begin{array}{r}63.15 \\
(12.64)\end{array}$ & $\begin{array}{r}62.55 \\
(13.59)\end{array}$ & $\begin{array}{r}64.40 \\
(13.54)\end{array}$ & $\begin{array}{r}63.13 \\
(14.97)\end{array}$ & $\begin{array}{r}64.04 \\
(14.23)\end{array}$ & $\begin{array}{r}65.84 \\
(10.87)\end{array}$ & $\begin{array}{l}67.08 \\
(9.59)\end{array}$ & $\begin{array}{r}68.45 \\
(13.96)\end{array}$ & $\begin{array}{r}62.75 \\
(15.31)\end{array}$ & $\begin{array}{r}60.65 \\
(12.18)\end{array}$ & $\begin{array}{r}64.18 \\
(13.15)\end{array}$ & $\begin{array}{r}63.77 \\
(13.72)\end{array}$ \\
\hline $\begin{array}{l}\text { Average BMI } \\
\text { scale }\left(\mathrm{kg} / \mathrm{m}^{\wedge} 2\right)\end{array}$ & $\begin{array}{r}0.549 \\
(34.86)\end{array}$ & $\begin{array}{r}0.500 \\
(33)\end{array}$ & $\begin{array}{r}0.493 \\
(32.73)\end{array}$ & $\begin{array}{r}0.521 \\
(33.79)\end{array}$ & $\begin{array}{r}0.377 \\
(28.32)\end{array}$ & $\begin{array}{r}0.391 \\
(28.85)\end{array}$ & $\begin{array}{r}0.507 \\
(33.26)\end{array}$ & $\begin{array}{r}0.430 \\
(30.34)\end{array}$ & $\begin{array}{r}0.455 \\
(31.29)\end{array}$ & $\begin{array}{r}0.480 \\
(32.24)\end{array}$ & $\begin{array}{r}0.482 \\
(32.31)\end{array}$ & $\begin{array}{r}0.480 \\
(32.24)\end{array}$ \\
\hline \multicolumn{13}{|l|}{ Race } \\
\hline White (\%) & 62.5 & 72.92 & 68.12 & 63.77 & 60 & 76 & 62.96 & 70.37 & 57.14 & 35.71 & 63.45 & 64.47 \\
\hline $\begin{array}{l}\text { African } \\
\text { American (\%) }\end{array}$ & 20.83 & 10.42 & 13.04 & 18.84 & 8 & 8 & 11.11 & 11.11 & 17.86 & 21.43 & 14.72 & 14.72 \\
\hline Other (\%) & 10.42 & 10.42 & 13.04 & 10.14 & 20 & 12 & 22.22 & 18.52 & 21.43 & 35.71 & 15.74 & 15.23 \\
\hline Missing (\%) & 6.25 & 6.25 & 5.8 & 7.25 & 12 & 4 & 3.7 & 0 & 3.57 & 7.14 & 6.09 & 5.58 \\
\hline Average $\mathrm{CCl}$ (std) & $\begin{array}{r}1.94 \\
(2.65)\end{array}$ & $\begin{array}{r}2.10 \\
(3.28)\end{array}$ & $\begin{array}{r}1.86 \\
(2.55)\end{array}$ & $\begin{array}{r}1.26 \\
(2.37)\end{array}$ & $\begin{array}{r}2.72 \\
(2.78)\end{array}$ & $\begin{array}{r}3.00 \\
(2.36)\end{array}$ & $\begin{array}{r}1.59 \\
(2.36)\end{array}$ & $\begin{array}{r}1.85 \\
(2.28)\end{array}$ & $\begin{array}{r}2.71 \\
(3.72)\end{array}$ & $\begin{array}{r}2.04 \\
(3.53)\end{array}$ & $\begin{array}{r}2.07 \\
(2.77)\end{array}$ & $\begin{array}{r}1.88 \\
(2.82)\end{array}$ \\
\hline \multicolumn{13}{|l|}{$\mathrm{CCl}$ Category } \\
\hline$A(0)(\%)$ & 47.92 & 54.17 & 47.83 & 62.32 & 28 & 20 & 44.44 & 40.74 & 42.86 & 53.57 & 44.16 & 50.76 \\
\hline $\mathrm{B}(1)(\%)$ & 14.58 & 4.17 & 13.04 & 11.59 & 12 & 8 & 22.22 & 22.22 & 10.71 & 14.29 & 14.21 & 11.17 \\
\hline C (2-3) (\%) & 12.5 & 16.67 & 18.84 & 13.04 & 32 & 36 & 18.52 & 14.81 & 17.86 & 10.71 & 18.78 & 16.75 \\
\hline $\mathrm{D}(4-5)(\%)$ & 10.42 & 14.58 & 5.8 & 7.25 & 12 & 12 & 7.41 & 14.81 & 7.14 & 7.14 & 8.12 & 10.66 \\
\hline
\end{tabular}




\begin{tabular}{|c|c|c|c|c|c|c|c|c|c|c|c|c|}
\hline$E(6+)(\%)$ & 14.58 & 10.42 & 14.49 & 5.8 & 16 & 24 & 7.41 & 7.41 & 21.43 & 14.29 & 14.72 & 10.66 \\
\hline Diabetic (\%) & 25 & 18.75 & 34.78 & 23.19 & 44 & 48 & 48.15 & 40.74 & 46.43 & 32.14 & 37.06 & 28.93 \\
\hline Smoker (\%) & 6.25 & 6.25 & 8.7 & 8.7 & 4 & 4 & 0 & 0 & 14.29 & 0 & 7.11 & 5.08 \\
\hline Female (\%) & 41.6 & 39.58 & 44.93 & 46.38 & 44 & 52 & 40.74 & 40.74 & 42.86 & 35.71 & 43.15 & 43.15 \\
\hline Hypertensive (\%) & 37.5 & 29.17 & 39.13 & 28.99 & 56 & 68 & 55.56 & 62.96 & 64.29 & 53.57 & 46.7 & 42.13 \\
\hline \begin{tabular}{|l} 
Elevated \\
Cholesterol (\%)
\end{tabular} & 8.33 & 6.25 & 10.14 & 2.9 & 16 & 28 & 7.41 & 11.11 & 7.14 & 14.29 & 9.64 & 9.64 \\
\hline \begin{tabular}{|l|} 
Chronic \\
Respiratory Issue \\
$(\%)$
\end{tabular} & 18.75 & 16.67 & 13.04 & 7.25 & 12 & 20 & 3.7 & 0 & 10.71 & 7.14 & 12.69 & 10.15 \\
\hline
\end{tabular}

Note: BMI described as $\mathrm{kg} / \mathrm{m}^{\wedge} 2$ and also rescaled to be between 0 and 1. Overall Cohort summary (two columns from the right) provided for reference only as study analysis aim was focused on specific days of CP administration. 
Table 2: Gray's equality test on CIF, Cause Specific Hazard Ratio and associated Cox regression p-Value for CP administration on specific days after non-Ig test based COVID-19 diagnosis. For example, the table shows that for CP administered on Day 0 the CIF did not differ for hospitalization duration or death analysis (Gray's Test is not $<=0.05$ ) and additionally while the odds of discharge and odds of death were both lower (Cause Specific Hazard Ratio column) neither were statistically significant (Cox regression is not $<=0.05)$.

\begin{tabular}{|l|l|l|l|l|l|}
\hline Analysis & Event & $\begin{array}{l}\text { Gray's Test } \\
\text { p-Value }\end{array}$ & $\begin{array}{l}\text { Cause Specific } \\
\text { Hazard Ratio }\end{array}$ & $\begin{array}{l}\text { 95\% Confidence } \\
\text { Intervals }\end{array}$ & $\begin{array}{l}\text { Cox Regression } \\
\text { p-Value }\end{array}$ \\
\hline CP @ Day 0 & Live Discharge & 0.77 & 0.69 & $0.43-1.11$ & 0.13 \\
\hline CP @ Day 0 & Death & 0.12 & 0.45 & $0.19-1.04$ & 0.06 \\
\hline CP @ Day 1 & Live Discharge & 0.34 & 0.74 & $0.51-1.07$ & 0.11 \\
\hline CP @ Day 1 & Death & 0.75 & 0.88 & $0.38-2.04$ & 0.76 \\
\hline CP @ Day 2 & Live Discharge & 0.48 & 0.94 & $0.51-1.75$ & 0.85 \\
\hline CP @ Day 2 & Death & 0.37 & 1.69 & $0.31-9.25$ & 0.55 \\
\hline CP @ Day 3 & Live Discharge & 0.73 & 0.86 & $0.46-1.60$ & 0.63 \\
\hline CP @ Day 3 & Death & 0.52 & 0.58 & $0.16-2.10$ & 0.41 \\
\hline CP @ Day 4 & Live Discharge & 0.64 & 1.37 & $0.70-2.70$ & 0.36 \\
\hline CP @ Day 4 & Death & 0.047 & 5.23 & $1.08-25.31$ & 0.04 \\
\hline
\end{tabular}


Table 3: Existing Randomized Controlled Trials (RCT) and Observational Studies on CP Administration Effectiveness as COVID-19 Treatment. The Last Row Summarizes the Results from this (Alamgir et al) N3C Study.

\begin{tabular}{|c|c|c|c|c|c|c|c|}
\hline Author & $\begin{array}{l}\text { Type of } \\
\text { Study }\end{array}$ & $\mathbf{N}(\%$ treated) & $\begin{array}{l}\text { Administration } \\
\text { Time Frame } \\
\text { (from } \\
\text { hospitalization } \\
\text { unless } \\
\text { otherwise } \\
\text { noted) }\end{array}$ & \begin{tabular}{|l|} 
Pandemic \\
Timefram \\
e
\end{tabular} & $\begin{array}{l}\text { Titer } \\
\text { Stratif- } \\
\text { ication }\end{array}$ & Country & Conclusion \\
\hline Joyner et al (4) & $\begin{array}{l}\text { Observatio } \\
\text { nal (no } \\
\text { matching) }\end{array}$ & $3,082(26.9 \%)$ & $<=72$ hours & $\begin{array}{l}\text { Apr } 42020 \\
- \text { Jul } 4 \\
2020\end{array}$ & Yes & USA & $\begin{array}{l}\text { Among patients hospitalized with Covid-19 who } \\
\text { were not receiving mechanical ventilation, } \\
\text { transfusion of plasma with higher } \\
\text { anti-SARS-CoV-2 IgG antibody levels was } \\
\text { associated with a lower risk of death than } \\
\text { transfusion of plasma with lower antibody levels. }\end{array}$ \\
\hline $\begin{array}{l}\text { Simonovich et } \\
\text { al (5) }\end{array}$ & RCT & $333(68.4 \%)$ & $\begin{array}{l}\text { Avg } 8(5-10) \\
\text { days from } \\
\text { symptom onset }\end{array}$ & $\begin{array}{l}\text { May } 28 \\
2020-\text { Aug } \\
272020\end{array}$ & N/A & Argentina & $\begin{array}{l}\text { No significant differences were observed in } \\
\text { clinical status or overall mortality between } \\
\text { patients treated with convalescent plasma and } \\
\text { those who received placebo. }\end{array}$ \\
\hline Libster et al (6) & RCT & $160(50 \%)$ & $<=72$ hours & $\begin{array}{l}\text { Jun } 42020 \\
- \text { Oct } 25 \\
2020\end{array}$ & N/A & Argentina & $\begin{array}{l}\text { Early administration of high-titer convalescent } \\
\text { plasma against SARS-CoV-2 to mildly ill infected } \\
\text { older adults reduced the progression of } \\
\text { Covid-19 (severe respiratory disease endpoint). }\end{array}$ \\
\hline Horby et al (7) & RCT & $\begin{array}{l}11,199 \\
(48.54 \%)\end{array}$ & $\begin{array}{l}\text { Avg } 9(6-12) \\
\text { days from } \\
\text { symptom onset }\end{array}$ & $\begin{array}{l}\text { May } 28 \\
2020-\text { Jan } \\
152021\end{array}$ & N/A & $\begin{array}{l}\text { United } \\
\text { Kingdom }\end{array}$ & $\begin{array}{l}\text { Among patients hospitalised with COVID-19, } \\
\text { high-titer convalescent plasma did not improve } \\
\text { survival or other prespecified clinical outcomes. }\end{array}$ \\
\hline $\begin{array}{l}\text { Agarwal et al } \\
(8)\end{array}$ & RCT & 464 (50.64\%) & N/A & $\begin{array}{l}\text { Apr } 22 \\
2020-\text { July } \\
142020\end{array} \mid$ & $N / A$ & India & $\begin{array}{l}\text { Convalescent plasma was not associated with a } \\
\text { reduction in progression to severe covid-19 or all } \\
\text { cause mortality }\end{array}$ \\
\hline
\end{tabular}




\begin{tabular}{|c|c|c|c|c|c|c|c|}
\hline Li et al (9) & RCT & $103(50.4 \%)$ & $<=72$ hours & $\begin{array}{l}\text { Feb } 14 \\
2020-\text { Apr } \\
12020\end{array}$ & $\mathrm{~N} / \mathrm{A}$ & China & $\begin{array}{l}\text { Among patients with severe or life-threatening } \\
\text { COVID-19, convalescent plasma therapy added } \\
\text { to standard treatment did not significantly } \\
\text { improve the time to clinical improvement within } \\
28 \text { days, although the trial was terminated early } \\
\text { and may have been underpowered to detect a } \\
\text { clinically important difference. }\end{array}$ \\
\hline $\begin{array}{l}\text { Janiaud et al } \\
\text { (10) }\end{array}$ & $\begin{array}{l}\text { Review } \\
\text { and } \\
\text { Meta-analy } \\
\text { sis }\end{array}$ & $\begin{array}{l}1,060 \\
(56.13 \%) \text { from } \\
\text { peer reviewed } \\
\text { RCTs only. }\end{array}$ & N/A & $\begin{array}{l}\text { Feb } 14 \\
2020-\text { Oct } \\
252020 \\
\text { (peer } \\
\text { reviewed } \\
\text { RCTs only) }\end{array}$ & $\mathrm{N} / \mathrm{A}$ & $\begin{array}{l}\text { India, } \\
\text { Argentina, } \\
\text { Bahrain, } \\
\text { China, The } \\
\text { Netherlands } \\
\text {, Spain, UK }\end{array}$ & $\begin{array}{l}\text { Treatment with convalescent plasma compared } \\
\text { with placebo or standard of care was not } \\
\text { significantly associated with a decrease in } \\
\text { all-cause mortality or with any benefit for other } \\
\text { clinical outcomes. }\end{array}$ \\
\hline $\begin{array}{l}\text { Rogers et al } \\
(11)\end{array}$ & $\begin{array}{l}\text { Observatio } \\
\text { nal (with } \\
\text { matching) }\end{array}$ & $241(36.15 \%)$ & $\begin{array}{l}\text { Avg } 7 \text { days from } \\
\text { symptom onset }\end{array}$ & $\begin{array}{l}\text { Pre May } \\
312020\end{array}$ & $\mathrm{~N} / \mathrm{A}$ & USA & $\begin{array}{l}\text { Treatment of severe COVID-19 with } \\
\text { convalescent plasma was not associated with a } \\
\text { significantly different risk of in-hospital mortality } \\
\text { or rate of hospital discharge as compared to } \\
\text { standard of care }\end{array}$ \\
\hline $\begin{array}{l}\text { Sostin et al } \\
\text { (12) }\end{array}$ & $\begin{array}{l}\text { Observatio } \\
\text { nal (with } \\
\text { matching) }\end{array}$ & $96(32.29 \%)$ & $\begin{array}{l}10(7-13) \text { days } \\
\text { from onsite, and } \\
3(2-5) \text { days } \\
\text { from } \\
\text { hospitalization }\end{array}$ & $\begin{array}{l}\text { Apr } 10 \\
2020- \\
\text { May } 5 \\
2020\end{array}$ & $\mathrm{~N} / \mathrm{A}$ & USA & $\begin{array}{l}\text { Convalescent plasma did not reduce in-hospital } \\
\text { mortality in our sample, nor did it reduce length } \\
\text { of stay. }\end{array}$ \\
\hline $\begin{array}{l}\text { Salazar et al } \\
\text { (13) }\end{array}$ & $\begin{array}{l}\text { Observatio } \\
\text { nal (with } \\
\text { matching) }\end{array}$ & $387(35.14 \%)$ & $\begin{array}{l}<=72 \text { hours } \\
\text { and }>72 \text { hours } \\
\text { (two groups) }\end{array}$ & $\begin{array}{l}\text { March } 28 \\
2020-\text { July } \\
62020\end{array}$ & & USA & $\begin{array}{l}\text { The data suggest that transfusion of high } \\
\text { anti-RBD IgG titer convalescent plasma early in } \\
\text { the hospital course significantly reduces } \\
\text { mortality }\end{array}$ \\
\hline Liu et al (14) & $\begin{array}{l}\text { Observatio } \\
\text { nal (with } \\
\text { matching) }\end{array}$ & $195(20 \%)$ & $\begin{array}{l}4 \text { days }(0-7 \\
\text { days })\end{array}$ & $\begin{array}{l}\text { Mar } 24 \\
2020-\mathrm{Apr} \\
82020\end{array}$ & Yes & USA & Survival improved in plasma recipients \\
\hline
\end{tabular}




\begin{tabular}{|c|c|c|c|c|c|c|c|}
\hline $\begin{array}{l}\text { Gharbharan } \\
\text { (15) }\end{array}$ & RCT & $86(50 \%)$ & $\begin{array}{l}2 \text { days (1-3 } \\
\text { days) }\end{array}$ & $\begin{array}{l}\text { Apr } 82020 \\
- \text { N/A }\end{array}$ & No & $\begin{array}{l}\text { The } \\
\text { Netherlands }\end{array}$ & $\begin{array}{l}\text { Most COVID-19 patients already have high } \\
\text { neutralizing antibody titers at hospital admission. } \\
\text { No difference in mortality, hospital stay was } \\
\text { observed between plasma treated patients and } \\
\text { patients on standard of care. Study terminated } \\
\text { early. }\end{array}$ \\
\hline $\begin{array}{l}\text { Budhiraja et al } \\
\text { (16) }\end{array}$ & $\begin{array}{l}\text { Observatio } \\
\text { nal (no } \\
\text { matching) }\end{array}$ & 694 (47.98\%) & N/A & $\begin{array}{l}\text { May } 1 \\
2020 \text { - Aug } \\
312020\end{array}$ & Yes & India & $\begin{array}{l}\text { In patients with COVID-19 admitted to ICU, } \\
\text { mortality was significantly lower in plasma arm. } \\
\text { This benefit of reduced mortality was most seen } \\
\text { in age group } 60 \text { to } 74 \text { years driven mostly by } \\
\text { females of this age group. Significant difference } \\
\text { in mortality was observed in patients with one } \\
\text { comorbidity. Moreover, patients on ventilator had } \\
\text { significantly lower mortality in the plasma arm; } \\
\text { particularly so for patients on invasive } \\
\text { mechanical ventilation }\end{array}$ \\
\hline $\begin{array}{l}\text { Alamgir et al } \\
\text { (This Study) }\end{array}$ & $\begin{array}{l}\text { Observatio } \\
\text { nal (with } \\
\text { matching) }\end{array}$ & $394(50 \%)$ & $\begin{array}{l}\text { Specifically } \\
(\text { Day } 0,1,2,3,4) \\
\text { from COVID-19 } \\
\text { diagnosis } \\
\text { analysis }\end{array}$ & $\begin{array}{l}\text { July } 1, \\
2020 \text { - } \\
\text { December } \\
19,2020\end{array}$ & No & USA & $\begin{array}{l}\text { No significant differences found in } \\
\text { hospitalization duration from treatment or } \\
\text { in-hospital mortality as a result of CP } \\
\text { administration on day } 0,1,2,3 \text { or } 4 \text { th day from } \\
\text { COVID-19 diagnosis. Day } 0 \mathrm{CP} \text { administration } \\
\text { showed a non-statistically significant effect on } \\
\text { reduced mortality odds. }\end{array}$ \\
\hline
\end{tabular}


medRxiv preprint doi: https://doi.org/10.1101/2021.05.04.21256627; this version posted May 8, 2021. The copyright holder for this preprint (which was not certified by peer review) is the author/funder, who has granted medRxiv a license to display the preprint in perpetuity.

It is made available under a CC-BY-NC 4.0 International license .

\section{FIGURES}

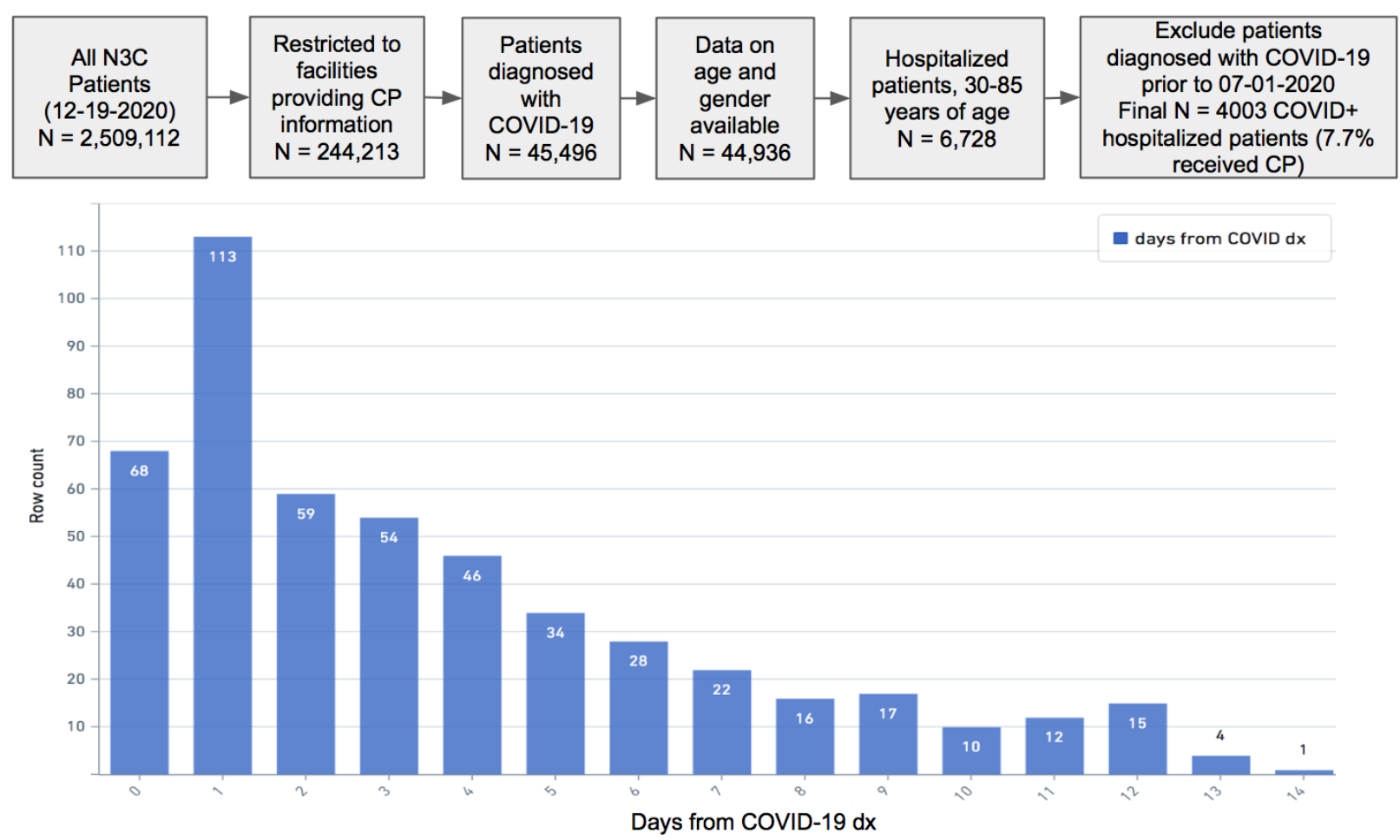

Figure 1: Data selection filter (top) and CP administration distribution from day of COVID-19+ diagnosis (bottom) in N3C (12-19-2020 release). 
medRxiv preprint doi: https://doi.org/10.1101/2021.05.04.21256627; this version posted May 8, 2021. The copyright holder for this preprint (which was not certified by peer review) is the author/funder, who has granted medRxiv a license to display the preprint in perpetuity.

It is made available under a CC-BY-NC 4.0 International license.

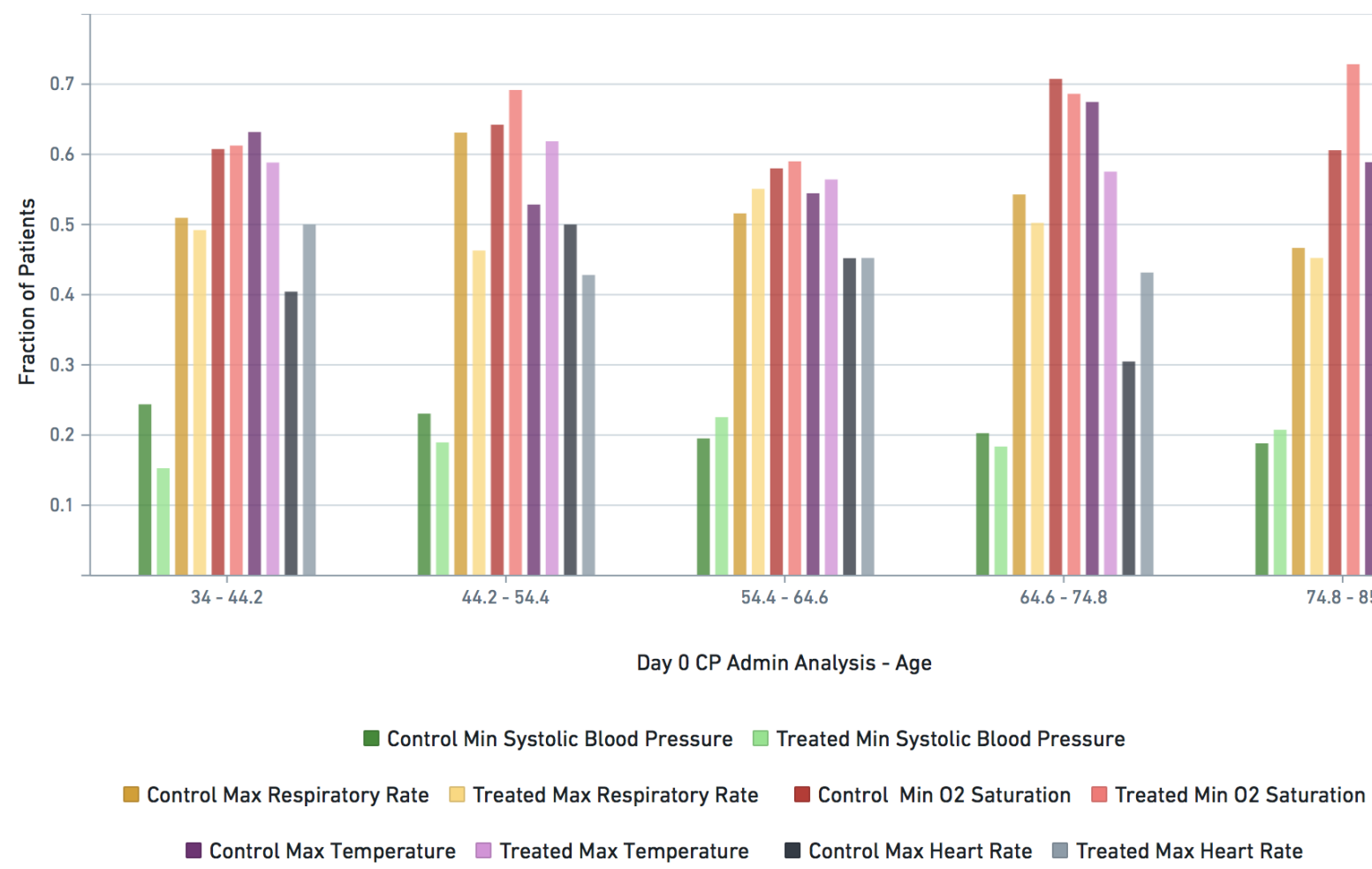

Figure 2: Patient state indicator distribution across age groups (as fraction of age group) for treated (with CP on Day 0) and matched control cohorts used for statistically significant clinical effect analysis. The darker shade of each colored pair is Control (untreated), while the lighter shade is Treated (with CP). For example, the dark purple (control cohort) and light purple (treated cohort) bars on each age group represent max temperature (normalized between 0 and 1). 
medRxiv preprint doi: https://doi.org/10.1101/2021.05.04.21256627; this version posted May 8, 2021. The copyright holder for this preprint (which was not certified by peer review) is the author/funder, who has granted medRxiv a license to display the preprint in perpetuity.

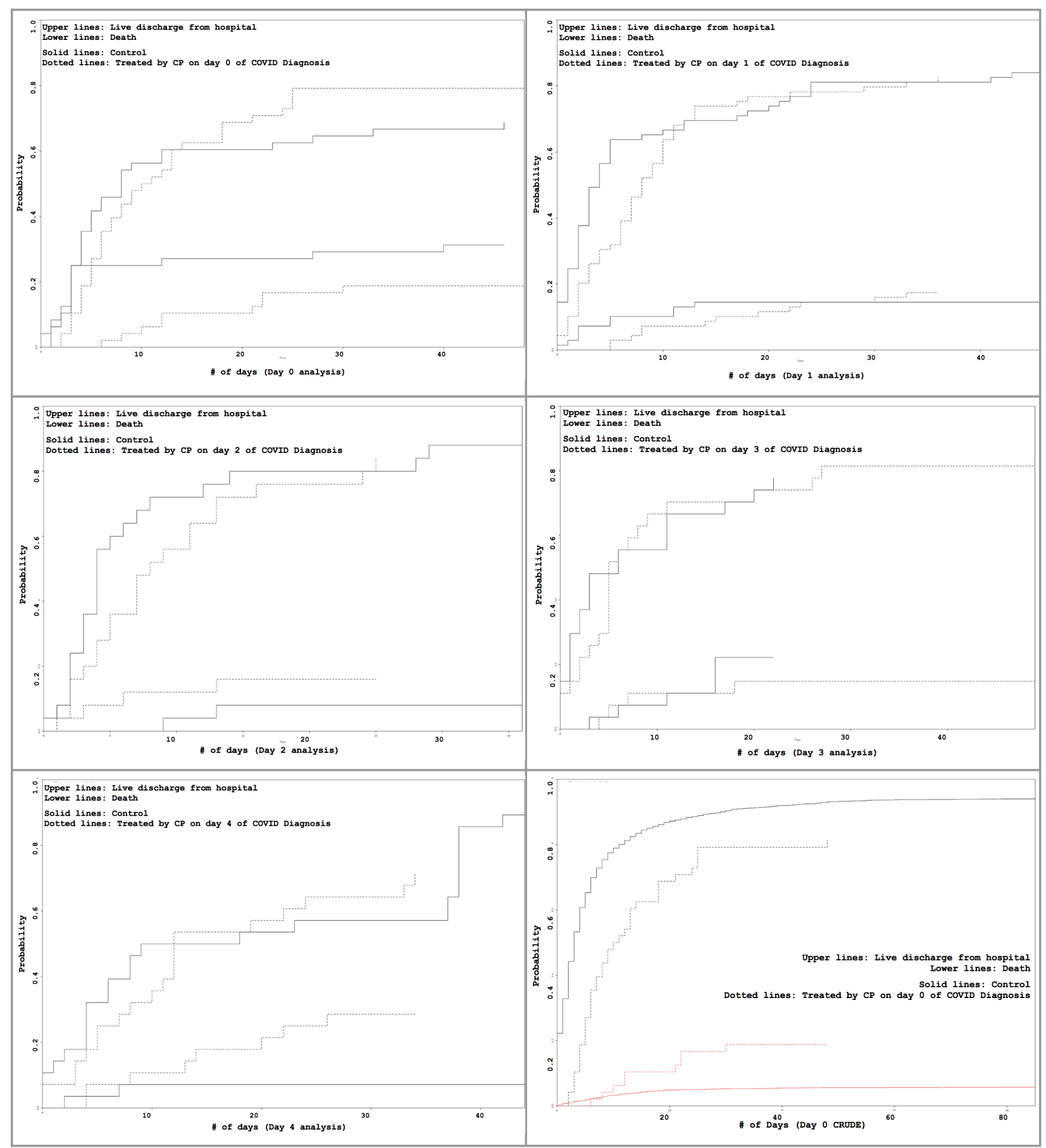

Figure 3: CP Administration on Day $X(X=0,1,2,3,4)$ CIF survival visualization with live hospital discharge duration as the primary endpoint and death as competing risk. Bottom right: CRUDE analysis without matching for day $0 \mathrm{CP}$ treatment.

Supplemental Appendix (including all R code used) is available at: https://www.ariscience.org/p3 sc2 paper 03.html 